\title{
Activation of cAMP signaling transiently inhibits apoptosis in vascular smooth muscle cells in a site upstream of caspase-3
}

Sergei N. Orlov ${ }^{\star 1}$, Nathalie Thorin-Trescases ${ }^{1}$, Nickolai O. Dulin ${ }^{2}$, Than-Vinh Dam ${ }^{1}$, Maria A. Fortuno ${ }^{1,3}$, Johanne Tremblay ${ }^{1}$ and Pavel Hamet ${ }^{1}$

1 Centre de Recherche du CHUM, Campus Hotel-Dieu, University of Montreal, Montreal, Quebec, Canada

${ }^{2}$ Medical College of Wisconsin, Milwaukee, Wisconsin, USA

${ }^{3}$ Current address: Vascular Physiology Unit, Faculty of Medicine, University of Navara, 31008 Pamplona, Spain

* corresponding author: Dr. SN Orlov, Laboratory of pathophysiology of ion transport disorders, Centre de Recherche du CHUM, Campus Hotel-Dieu, 3850 rue St-Urbain, Montreal, Quebec, H2W 1T8, Canada,

tel:(514)-843-2925; e-mail: orlovs@ere.umontreal.ca

Received 12.1.98; revised 23.3.99; accepted 14.5.99

Edited by C. Thiele

\begin{abstract}
Intracellular signaling pathways that are involved in protection of vascular smooth muscle cells (VSMC) from apoptosis remain poorly understood. This study examines the effect of activators of CAMP/cGMP signaling on apoptosis in nontransfected VSMC and in VSMC transfected with c-myc (VSMC-MYC) or with its functional analogue, E1A-adenoviral protein (VSMC-E1A). Serum-deprived VSMC-E1A exhibited the highest apoptosis measured as the content of chromatin and low molecular weight DNA fragments, phosphatidylserine content in the outer surface of plasma membrane and caspase- 3 activity (ten-, five-, four- and tenfold increase after $6 \mathrm{~h}$ of serum withdrawal, respectively). In VSMC-E1A, the addition of an activator of adenylate cyclase, forskolin, abolished chromatin cleavage, DNA laddering, caspase-3 activation and the appearance of morphologically-defined apoptotic cells triggered by $6 \mathrm{~h}$ of serum deprivation. In nontransfected VSMC and in VSMC-MYC, $6 \mathrm{~h}$ serum deprivation led to $\sim$ six- and threefold activation of chromatin cleavage, respectively, that was also blocked by forskolin. In VSMC-E1A, inhibition of apoptosis was observed with other activators of cAMP signaling (cholera toxin, isoproterenol, adenosine, 8$\mathrm{Br}$-cAMP), whereas $6 \mathrm{~h}$ incubation with modulators of cGMP signaling (8-Br-cGMP, nitroprusside, atrial natriuretic peptide, L-NAME) did not affect the development of apoptotic machinery. The antiapoptotic effect of forskolin was abolished in $24 \mathrm{~h}$ of serum deprivation that was accompanied by normalization of intracellular cAMP content and protein kinase A (PKA) activity. Protection of VSMC-E1A from apoptosis by forskolin was blunted by PKA inhibitors (H-89 and KT5720), whereas transfection of cells with PKA catalytic subunit attenuated apoptosis triggered by serum withdrawal.
\end{abstract}

The protection of VSMC-E1A by forskolin from apoptosis was insensitive to modulators of cytoskeleton assembly (cytochalasin B, colchicine). Neither acute (30 min) nor chronic (24 h) exposure of VSMC to forskolin modified basal and seruminduced phosphorylation of the MAP kinase ERK1/2. Thus, our results show that activation of CAMP signaling delays the development of apoptosis in serum-deprived VSMC at a site upstream of caspase-3 via activation of PKA and independently of CAMP-induced reorganization of the cytoskeleton network and the ERK1/2-terminated MAPK signaling cascade.

Keywords: smooth muscle; apoptosis; cyclic AMP; protein kinase A; caspase-3

\section{Introduction}

Both vascular smooth muscle cell (VSMC) growth and programmed cell death contribute to the altered geometry of vessels in hypertension, ${ }^{1,2}$ the development of artherosclerotic plaques ${ }^{3,4}$ and regression of vascular hypertrophy under treatment of cardiovascular complications of these diseases. ${ }^{5}$ Much is known about the pharmacological regulation of VSMC replication (for review see ${ }^{6,7}$ ), which is in contrast with the lack of systematic studies on the pharmacology of VSMC apoptosis. Similarly to the majority of cells investigated so far, apoptosis in VSMC can be triggered by the withdrawal of growth factors. ${ }^{1,4,8}$ The ligands of Fas/Apo-1/CD95, a novel member of the tumor necrosis factor (TNF) receptor family, trigger apoptosis in p53-transfected VSMC $^{9}$ as well as in VSMC from human atherosclerotic plaques subjected to chronic exposure to $\mathrm{T}$ lymphocyte-derived interferon- $\gamma$, macrophage-derived TNF and interleukin- $1^{10,11}$ but do not affect apoptosis in VSMC from normal vessels. ${ }^{9,11}$ Apoptosis in serum-deprived VSMC is potentiated by overexpression of c-myc, E1A adenovirus, co-expression of p53 with c-mycl $E 1 A$, and is inhibited by overexpression of bcl-2. ${ }^{4,8,12}$ However, intracellular signaling pathways controlling the expression and functional activity of these gene products are poorly understood.

It is well-documented that bcl-2, p53 as well as gene products involved in cell cycle progression, such as retinoblastoma gene product, cyclins and cyclin-dependent proteases and phosphatases, are subjected to serine/ threonine phosphorylation, ${ }^{13-15}$ suggesting the role of serine/threonine protein kinases, including cyclic nucleotide-dependent protein kinases, in the regulation of apoptotic machinery. To motivate our study, it is important to underline that data on the involvement of cAMP and cGMP signaling systems in apoptosis demonstrate an extreme tissue-specificity and dependence on the origin of apoptotic stimulus. In the majority of studies, including 
myeloid leukemia cells, ${ }^{16}$ primary granulosa cells, ${ }^{17}$ thymocytes, ${ }^{18-20}$ embryonic epithelial cells, ${ }^{21}$ elevation of cAMP triggered apoptosis, whereas in neutrophils and nerve tissue, it prevented the development of apoptotic machinery. $22-24$ In T lymphocytes, activation of cAMP signaling did not affect CD95-induced apoptosis as well as apoptosis induced by etoposide, dexamethasone and thapsigargin, whereas activation of cGMP-dependent protein kinase (PKG) partially inhibited CD95-induced apoptosis. ${ }^{25,26}$ On the contrary, in leukemic HL-60 cells, apoptosis can be triggered by nitric oxide donors and partially inhibited by cAMP. ${ }^{27}$ cGMP potentiated apoptosis in neonatal rat cardiac myocytes but did not affect the death of cardiac fibroblasts. ${ }^{28}$

This study specifically examines the role of cAMP and cGMP signaling in the development of apoptosis in cultured VSMC from the rat aorta. Our results show that activation of cAMP signaling delays VSMC apoptosis by acting on a step upstream of caspase-3. In contrast to CAMP, apoptosis in VSMC is insensitive to activation of the cGMP signaling pathway.

\section{Results}

\section{Kinetics of chromatin cleavage in serum-deprived cells}

The study of cross-talk of signals involved in the induction and progression of VSMC programmed death is complicated due to the low activity of the apoptotic pathway in these cells. ${ }^{1,4}$ To overcome this problem, we used cells transfected with c-myc (VSMC-MYC) or its functional analogue, E1A-adenoviral protein (VSMC-E1A). Previously, it was shown that in the absence of growth factors these cells are still actively cycling and undergo massive apoptosis. ${ }^{12}$

The initial content of chromatin fragments used as a well-documented marker of apoptosis was about the same in non-transfected VSMC as in VSMC-MYC and VSMC$\mathrm{E} 1 \mathrm{~A}(0.4-0.7 \%)$ and was increased after $24 \mathrm{~h}$ incubation in the presence of $10 \%$ calf serum up to $2.51 \pm 0.32$, $3.71 \pm 0.30$ and $5.01 \pm 0.46 \%$ in VSMC, VSMC-MYC and VSMC-E1A cells, respectively. In contrast to baseline conditions, chromatin cleavage in serum-depleted medium was drastically potentiated by transfection with c-myc and E1A-adenovirus, reaching 4, 10 and $25 \%$ after $6 \mathrm{~h}$ of serum deprivation in VSMC, VSMC-MYC and VSMC-E1A, respectively (Figure 1a).

The drastic potentiation of apoptosis in serum-deprived VSMC-E1A compared to non-transfected cells was confirmed by analysis of DNA laddering (Figure 1b), relative content of phosphatidylserine on the outer leaflet of plasma membrane (Figure 2) and by morphological evaluation of the appearance of apoptotic cells (Figures 3 and 4). Figure $1 \mathrm{~b}$ shows that the content of low molecular weight 3 '-end labeled DNA fragments was higher by $\sim$ tenfold in serum-deprived VSMC-E1A compared to non-transfected cells. Two populations of cells possessing high and low fluorescent signal (HF- and LF-cells, respectively) were revealed by annexin-V-Fluos binding assay (Figure $2 a$ and b). In non-transfected VSMC the amount of HF-cells caused by enhanced content of phosphatidylserine on the outer surface of plasma membrane did not exceed $\sim 2 \%$ and was independent of acute serum deprivation (data not shown). In contrast, the content of high fluorescent VSMC-E1A was increased after $6 \mathrm{~h}$ of serum deprivation by $\sim$ fourfold (Figure $2 \mathrm{c}$ ). It
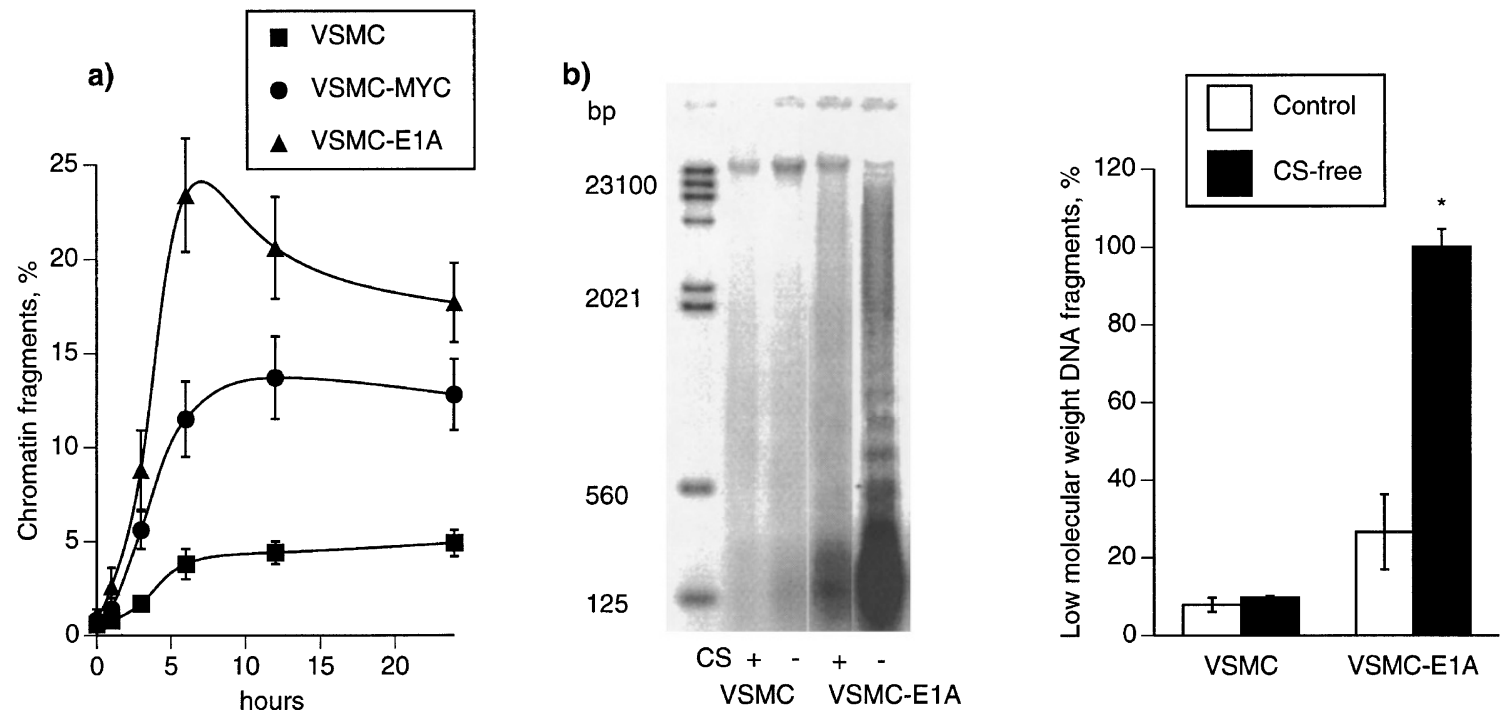

Figure 1 Apoptosis in non-transfected vascular smooth muscle cells (VSMC) and in VSMC transfected with c-myc (VSMC-MYC) or E1A-adenovirus (VSMC-E1A). (a) Time-course of the accumulation of intracellular chromatin fragments in VSMC, VSMC-MYC and VSMC-E1A induced by serum withdrawal. Means \pm S.E. from experiments performed in quadruplicate are given. (b) Effect of serum deprivation on DNA laddering (left panel) and relative content of low molecular weight $(1500-125 \mathrm{bp}) 3^{\prime}$-end labeled DNA fragments (right panel) in VSMC and E1A-VSMC. Cells were incubated in the presence (+) or absence (-) of $10 \%$ calf serum (CS) for $6 \mathrm{~h}$. The content of low molecular weight DNA fragments in serum-deprived VSMC-E1A was taken as $100 \%$. Data from three experiments are shown as means \pm S.E. ${ }^{*} P<0.01$ compared to control 
should be mentioned that baseline content of HF-cells (Figure 2a) is probably overestimated due to partial induction of apoptosis in VSMC-E1A under their trypsinization and staining in serum-free medium.

Phase contrast microscopy did not reveal any significant effect of $6 \mathrm{~h}$ serum deprivation on VSMC morphology (Figure $3 \mathrm{~A}$ and $\mathrm{B}$ ). In contrast, serum deprivation of VSMCE1A led to drastic accumulation of rounded cells which were preferentially localized in the incubation medium (Figure 3D vs C). The detachment of the major part of apoptotic cells was further confirmed by analysis of Hoechst 33258-positive cells. The number of Hoechstpositive VSMC attached to plastic support $(5 \pm 2 \%)$ was not significantly affected by $6 \mathrm{~h}$ serum deprivation, whereas in VSMC-E1A this parameter was increased from $12 \pm 2$ to $24 \pm 6 \%$ (Figure $4 \mathrm{~A}$ panels $\mathrm{a}-\mathrm{c}$ ). Using serum-supplied and serum-deprived VSMC, we did not observe Hoechstpositive cells in the incubation medium; the negative result was also obtained with serum-supplied VSMC-E1A (data not shown). On the contrary, in serum-deprived VSMC-E1A a)

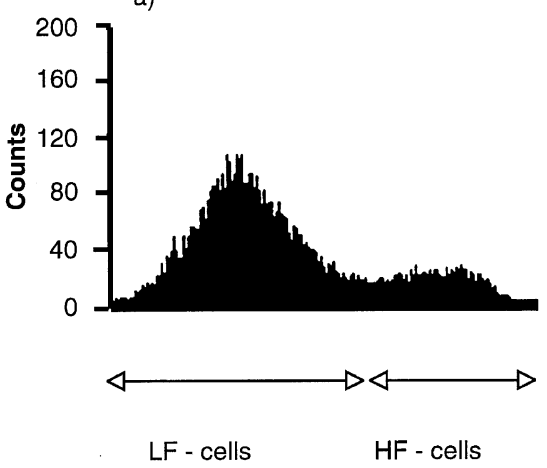

b)

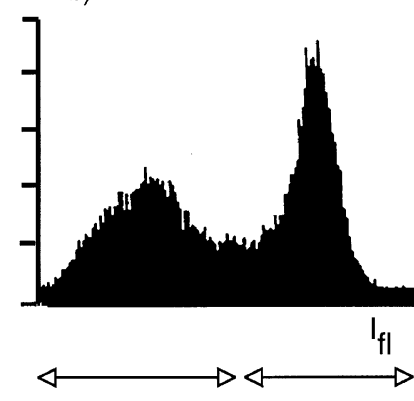

LF - cells HF - cells

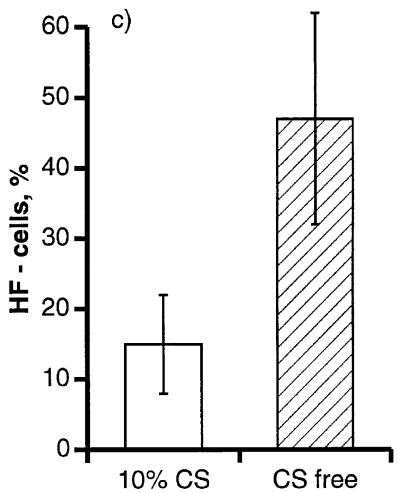

Figure 2 Analysis of the relative content of phosphatidylserine on the outer leaflet of VSMC-E1A using annexin V-Fluos. The representative distributions of cells with low (LF) and high (HF) fluorescence in the presence of $10 \%$ calf serum and after $6 \mathrm{~h}$ of incubation in serum deprived medium are shown in panels (a) and (b), respectively. (c) The relative content of HF-VSMC-E1A in the presence of serum and after $6 \mathrm{~h}$ of serum deprivation. The total content of HF- and LF-cells was taken as $100 \%$. Means \pm S.D. obtained in three experiments are given
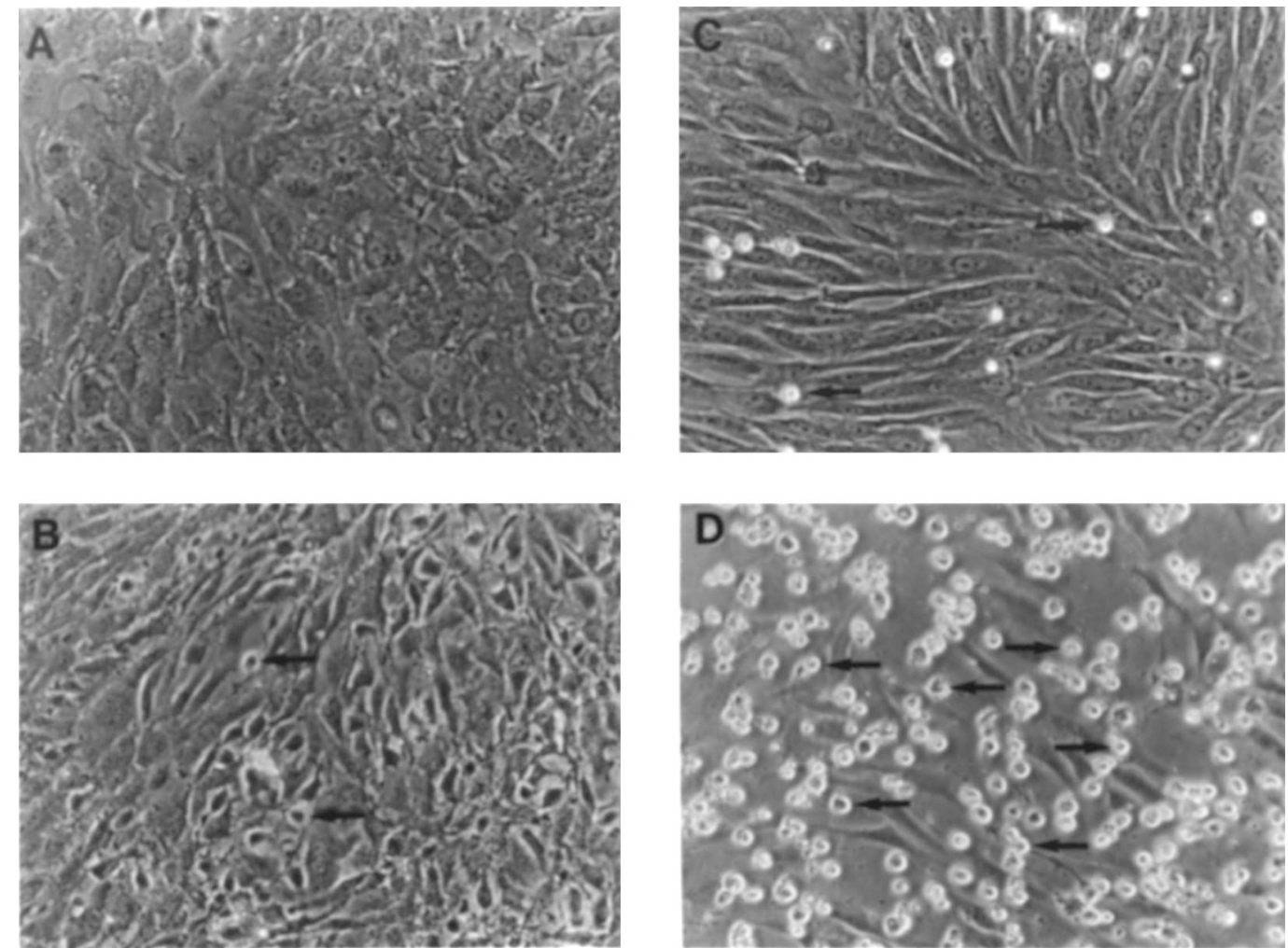

Figure 3 Phase-contrast microscopy of $\operatorname{VSMC}(\mathbf{A}, \mathbf{B})$ and VSMC-E1A $(\mathbf{C}, \mathbf{D})$ after $6 \mathrm{~h}$ of incubation in the presence of $10 \%$ calf serum $(\mathbf{A}, \mathbf{C})$ or in serum-deprived medium (B, D). Apoptotic cells are shown by arrows 
A
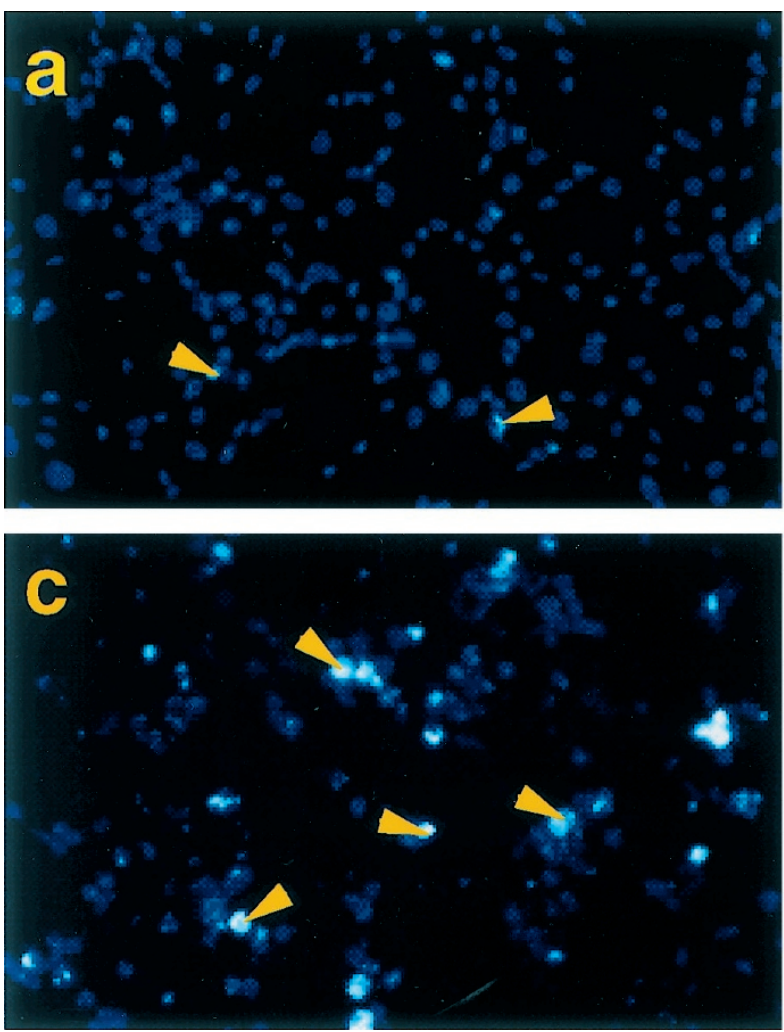

a

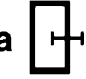

b

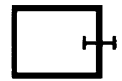

c

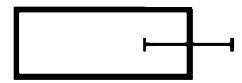

d
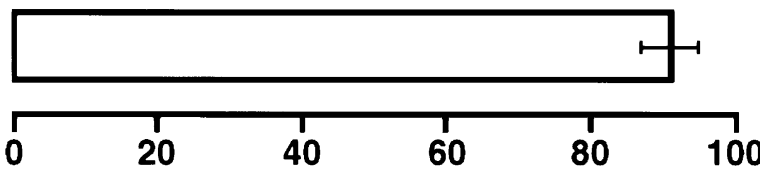

Hoechst positive cells, \%

Figure 4 (A) Fluorescent microscopy of VSMC (a) and VSMC-E1A (b-d) attached to plastic support (a-c) or localized in the incubation medium (d) and stained with Hoechst 33258 . Cells were incubated during $6 \mathrm{~h}$ in the presence $(\mathbf{b})$ or absence $(\mathbf{a}, \mathbf{c}, \mathbf{d})$ of $10 \%$ calf serum. Hoechst-positive cells are shown by arrows. (B) The relative amount of Hoechst-positive VSMC (a) and VSMC-E1A (b-d) attached to plastic support (a-c) or localized in the incubation medium (d) after $6 \mathrm{~h}$ incubation in the presence (b) or absence $(\mathbf{a}, \mathbf{c}, \mathbf{d})$ of $10 \%$ calf serum. Means \pm S.E. obtained in three experiments counted in $3-4$ different areas are given

virtually all cells in the incubation medium were stained with Hoechst 33258 (Figure 4A panel d).

Keeping in mind the highest susceptibility of VSMC-E1A to undergo apoptosis and the highest increase of chromatin cleavage after $6 \mathrm{~h}$ of incubation, the effect of modulators of cAMP/cGMP signaling on the content of chromatin fragments in these cells and at this time-point have been studied in the bulk of experiments. The major findings from these experiments were further examined with VSMC-MYC and non-transfected VSMC. The data on the preferential localization of apoptotic cells in the incubation medium were used for the study of apoptosis in cells transiently transfected with PKA (see below).

\section{Modulation of apoptosis by activators of cAMP and cGMP signaling}

The data presented in Table 1 show that the permeable analogue of CAMP, 8-Br-cAMP, decreased chromatin cleavage induced by $6 \mathrm{~h}$ incubation of VSMC-E1A in serum- 
deprived medium by $80-90 \%$. Inhibition of apoptosis was also observed under elevation of intracellular cAMP with an inhibitor of phosphodiesterase, Ro-20 1724, an activator of $\mathrm{G}_{\mathrm{s}}$-protein, cholera toxin, and an activator of adenylate cyclase, forskolin. In VSMC, intracellular cAMP content can also be increased via activation of $\beta$-adrenergic ${ }^{29}$ and $\mathrm{A}_{2}$ adenosine receptors. ${ }^{30}$ Both adenosine and the $\beta$-adrenergic agonist isoproterenol potentiated the antiapoptotic action of Ro-20 1724. Drastic inhibition of chromatin cleavage with forskolin, observed in VSMC-E1A, was also revealed in VSMC-MYC and in non-transfected VSMC subjected to $6 \mathrm{~h}$ of serum withdrawal (Table 1).

The antiapoptotic action of cAMP was further confirmed by analysis of $3^{\prime}$-end DNA labeling and by phase contrast microscopy. In serum-deprived VSMC-E1A, addition of forskolin decreased the accumulation of low molecular weight DNA fragments by 6-7-fold (Figure 5b) and prevented the appearance of morphologically defined apoptotic cells (Figure 5c). The cell shape transition (arborization) seen in forskolin-treated serum-deprived VSMC-E1A (Figure 5c, panel D) was consistent with data obtained with non-transfected VSMC treated with forskolin and other activators of CAMP signaling. ${ }^{31-33}$ In contrast to cAMP, modulators of cGMP signaling, such as 8-Br-cGMP, an inhibitor of nitric oxide synthase, L-NAME, and activators of membrane-bound and soluble guanylate cyclase, atrial natriuretic peptide (ANP) and nitroprusside, respectively, did not significantly affect baseline and serum deprivationinduced chromatin cleavage in VSMC-E1A (Table 2).

\section{Caspase-3 activity}

Using a substrate and inhibitor of the caspase-1 subfamily (YVAD-AMC and Ac-YVAD-CHO, respectively), we did not

Table 1 Effect of activators of cAMP signaling on chromatin cleavage in nontransfected vascular smooth muscle cells (VSMC) and in VSMC transfected with c-myc (VSMC-MYC) or E1A adenovirus (VSMC-E1A)

\begin{tabular}{|c|c|c|}
\hline \multirow[b]{2}{*}{ Type of cells/additions } & \multicolumn{2}{|c|}{ Chromatin fragments, $\%$} \\
\hline & $10 \% \mathrm{CS}$ & CS-free \\
\hline \multicolumn{3}{|l|}{ VSMC-E1A } \\
\hline Control & $2.7 \pm 0.5$ & $23.4 \pm 2.8$ \\
\hline 8-Br-cAMP, 1 mM & $3.0 \pm 0.5$ & $6.1 \pm 0.8^{\star *}$ \\
\hline Ro-20 1724, $20 \mu \mathrm{M}$ & $2.8 \pm 0.4$ & $16.1 \pm 1.9^{*}$ \\
\hline Cholera toxin, $0.5 \mu \mathrm{g} / \mathrm{ml}$ & $2.1 \pm 0.4$ & $8.3 \pm 2.2^{\star \star}$ \\
\hline Forskolin, $10 \mu \mathrm{M}$ & $1.9 \pm 0.6$ & $5.6 \pm 1.0 * *$ \\
\hline Ro-20 1724+isoproterenol, $10 \mu \mathrm{M}$ & $2.1 \pm 0.8$ & $11.5 \pm 2.7^{*}$ \\
\hline Ro-20 1724+adenosine, $100 \mu \mathrm{M}$ & $2.2 \pm 0.6$ & $10.0 \pm 1.9^{*}$ \\
\hline \multicolumn{3}{|l|}{ VSMC-MYC } \\
\hline Control & $2.2 \pm 0.4$ & $13.1 \pm 1.8$ \\
\hline Forskolin, $10 \mu \mathrm{M}$ & $1.9 \pm 0.3$ & $2.6 \pm 0.3^{\star *}$ \\
\hline \multicolumn{3}{|l|}{ VSMC } \\
\hline Control & $0.9 \pm 0.1$ & $3.4 \pm 0.4$ \\
\hline Forskolin, $10 \mu \mathrm{M}$ & $1.0 \pm 0.1$ & $1.6 \pm 0.1^{*}$ \\
\hline
\end{tabular}

Cells were preincubated with the compounds listed in the left column in the presence of $10 \%$ calf serum (CS) during $30 \mathrm{~min}$ or $3 \mathrm{~h}$ (cholera toxin). Then, the medium was aspirated and the cells were incubated for the next $6 \mathrm{~h}$ with the same compounds in the presence or absence of calf serum. Data from three experiments performed in triplicate are shown as mean \pm S.E. ${ }^{*} P<0.05$ and ${ }^{* *} P<0.001$, as compared to the controls (non-treated cells) observe any activation of this enzyme in VSMC and VSMCE1A undergoing apoptosis (data not shown), whereas caspase-3 activity was increased by tenfold after $6 \mathrm{~h}$ incubation of VSMC-E1A in serum-depleted medium. Forskolin decreased the baseline activity of caspase-3 and sharply inhibited its increment induced by serum deprivation (Table 3).

\section{Role of protein kinase $A$}

To examine the role of PKA in the inhibition of apoptosis by activators of cAMP signaling, we (i) compared kinetics of modulation by forskolin of chromatin cleavage, CAMP production and PKA activation in VSMC-E1A and in nontransfected VSMC; (ii) examined effect of protein kinase inhibitors on apoptosis in VSMC-E1A; and (iii) transiently transfected VSMC-E1A with catalytic subunit of PKA. Both in VSMC-E1A and in non-transfected VSMC, the inhibition of chromatin cleavage by an activator of adenylate cyclase, forskolin, was abolished under prolonged ( $24 \mathrm{~h}$ ) incubation (Figure 6). The slight potentiation of apoptosis observed in forskolin-treated cells after $24 \mathrm{~h}$ is in accordance with previously reported data. ${ }^{1}$ This transient inhibition of apoptosis by forskolin was consistent with transient elevation of intracellular cAMP content and PKA activity and normalization of these parameters after $24 \mathrm{~h}$ incubation (Figure 7).

The addition of potent inhibitors of PKA, KT 5720 and $\mathrm{H}$ $89 \mathrm{IC}_{50}$ for PKA and PKG $\sim 0.05$ and $0.5 \mu \mathrm{M}$, respectively ${ }^{34}$ did not affect the content of chromatin fragments in serum-supplied and serum-deprived VSMC-E1A, but reduced the forskolin-induced inhibition of chromatin cleavage in serum-deprived VSMC-E1A to 61 and $47 \%$, respectively, as compared with $81 \%$ of inhibition observed in the absence of these compounds (Table 4). In contrast to KT 5720 and $\mathrm{H}-89$, apoptosis in forskolin-treated cells was insensitive to the less potent inhibitor of PKA, compound $\mathrm{H}$ $8\left(\mathrm{IC}_{50}\right.$ for PKA, and PKG 1.2 and $0.5 \mu \mathrm{M}$, respectively $\left.{ }^{35}\right)$.

To further examine the role of PKA in the inhibition of apoptosis, we transiently transfected VSMC-E1A with catalytic subunit of PKA. It should be underlined, however, that low efficiency of transient transfection ( 10-20\%) complicates the study of the effect of PKA on apoptosis in the total population of cells. To overcome this problem, we co-transfected VSMC-E1A with luciferase and compared the intensity of luminescence in attached cells and in medium. This approach is based on the observation that apoptotic VSMC-E1A cells are mainly localized in the incubation medium (Figures 3 and 4). Figure 8 shows that the intensity of luminescence in medium from control and PKAtransfected cells in the presence of calf serum was not different, whereas an increment of luminescence triggered by induction of apoptosis in serum-deprived medium was $\sim$ twofold less in VSMC-E1A transfected with PKA compared to cells transfected with empty vector (25 and $47 \%$, respectively, $P<0.02)$.

\section{Role of cytoskeleton network and MAP kinases}

Activation of CAMP signaling leads to transient shape transition (arborization) of VSMC which is abolished after 
a)

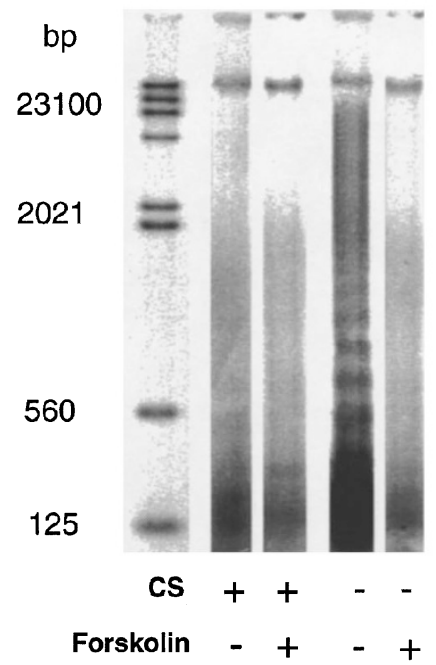

c)
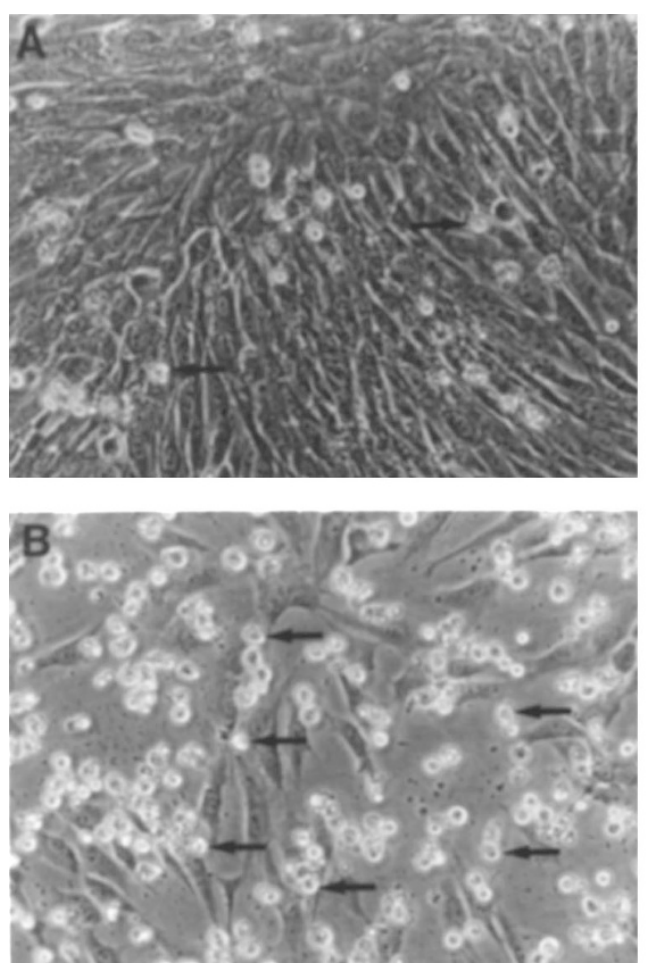

b)

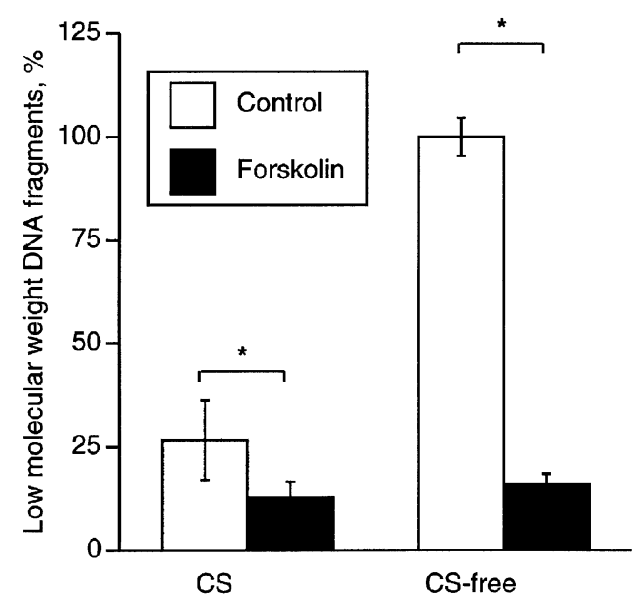

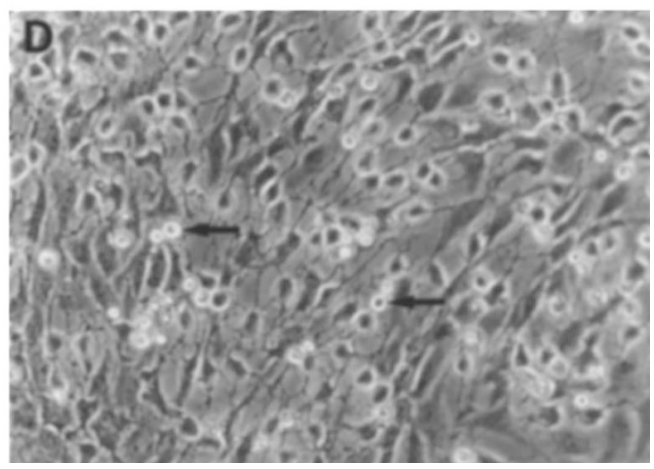

Figure 5 Effect of forskolin on apoptosis in serum-deprived VSMC-E1A. The cells were preincubated in the presence $(+)$ or absence $(-)$ of $10 \mu \mathrm{M}$ forskolin and $10 \%$ calf serum (CS) for $6 \mathrm{~h}$. (a) $3^{\prime}$-end DNA laddering and (b) relative content of low molecular weight (1500 - $125 \mathrm{bp}$ ) 3'-end labeled DNA fragments. The relative amount of DNA fragments in serum-deprived VSMC-E1A in the absence of forskolin was taken as 100. Data from experiment performed in triplicate are shown as means + S.E. ${ }^{*} P<0.01$. (c) Phase-contrast microscopy of VSMC-E1A after $6 \mathrm{~h}$ of incubation in the presence of $10 \%$ calf serum $(\mathbf{A}, \mathbf{C})$ or in serum-deprived medium (B, D) without (A, B) or with $10 \mu \mathrm{M}$ forskolin (C, D). Apoptotic cells are shown by arrows

normalization of intracellular cAMP content. ${ }^{29,31-33}$ Considering this, it may be assumed that the transient inhibition of apoptosis in VSMC by CAMP (Figure 6) is mediated via cytoskeleton reorganization. However, this assumption contradicts several observations. Indeed, substances that disintegrate actin filaments, such as cytochalasin B, cause arborization of VSMC similar to that observed in cAMP- treated VSMC, whereas colchicine, a substance interfering with the assembly-disassembly of microtubules, prevents cAMP-induced arborization of VSMC. ${ }^{29,31,32}$ However, neither cytochalasin nor colchicine affected baseline apoptosis in VSMC-E1A and its modulation by forskolin (Table 5). In addition, in contrast to non-transfected VSMC (Figure 5c), VSMC-MYC did not undergo arborization in the presence of 
Table 2 Effect of modulators of cGMP signaling on chromatin cleavage in VSMC-E1A

\begin{tabular}{lcc}
\hline & \multicolumn{2}{c}{ Chromatin fragment, \% } \\
Additions, mM & 10\% CS & CS-free \\
\hline Control & $3.0 \pm 0.5$ & $24.7 \pm 3.0$ \\
8-Br-cGMP, 1 & $2.8 \pm 0.5$ & $23.9 \pm 2.7$ \\
L-NAME, 2 & $3.2 \pm 0.7$ & $24.3 \pm 2.8$ \\
ANP, 0.001 & $3.1 \pm 0.3$ & $23.4 \pm 3.2$ \\
Nitroprusside, 0.5 & $4.8 \pm 1.0$ & $31.1 \pm 4.8$ \\
\hline
\end{tabular}

Cell were preincubated with the compounds listed in the left column in the presence of $10 \%$ calf serum (CS) for $30 \mathrm{~min}$. Then, the medium was aspirated and cells were incubated for the next $6 \mathrm{~h}$ with the same compounds in the presence or absence of calf serum. Data from three experiments performed in quadruplicate are shown as means \pm S.E.

Table 3 Effect of forskolin on caspase-3 activity in VSMC-E1A

\begin{tabular}{|c|c|c|}
\hline \multirow[b]{2}{*}{ Additions } & \multicolumn{2}{|c|}{$\begin{array}{l}\text { Caspase-3 activity, nmol } \\
\quad(\mathrm{mg} \text { protein) })^{-1} \mathrm{~h}^{-1}\end{array}$} \\
\hline & $\begin{array}{l}\text { Serum-supplied } \\
\text { cells }\end{array}$ & $\begin{array}{l}\text { Serum-deprived } \\
\text { cells }\end{array}$ \\
\hline None (control) & $0.36 \pm 0.21$ & $3.99 \pm 0.78$ \\
\hline Forskolin, $10 \mu \mathrm{M}$ & $0.08 \pm 0.03^{*}$ & $0.65 \pm 0.30^{*}$ \\
\hline
\end{tabular}

Cells were incubated for $6 \mathrm{~h}$ in the presence or absence of $10 \%$ calf serum with or without forskolin, and caspase- 3 activity was measured in the cell lysate as indicated in Materials and Methods. Data from three experiments performed in triplicate are shown as means \pm S.E. ${ }^{*} P<0.001$ as compared with the control

a)

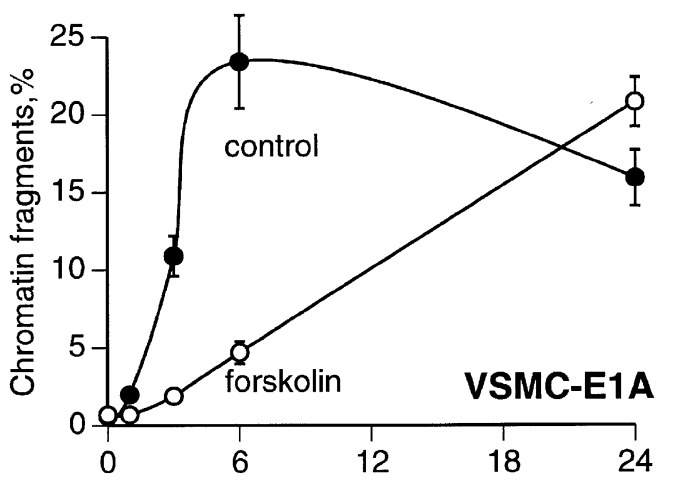

b)

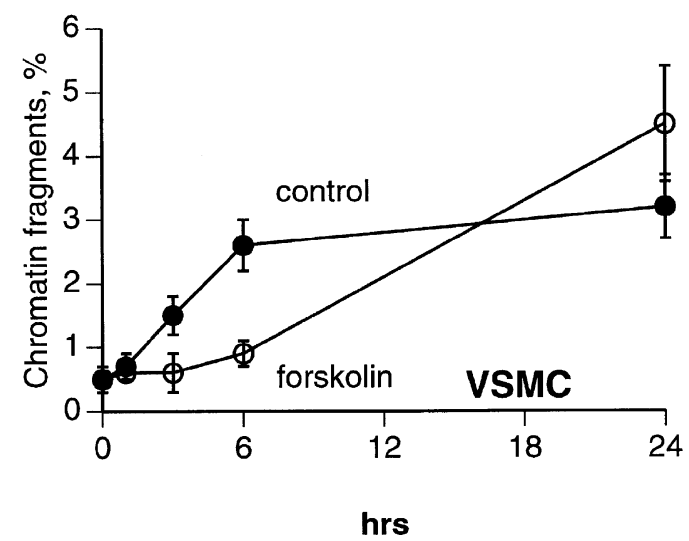

Figure 6 Kinetics of modulation by forskolin $(10 \mu \mathrm{M})$ of chromatin cleavage triggered by serum deprivation in VSMC-E1A (a) and in non-transfected VSMC (b). Data from two (VSMC) and three (E1A-VSMC) experiments performed in quadruplicate are shown as means \pm S.E
Table 4 Effect of protein kinase inhibitors on chromatin cleavage in VSMC-E1A

\begin{tabular}{lcc}
\hline & \multicolumn{2}{c}{ Chromatin fragments, \% } \\
Additions, $\mu \mathbf{M}$ & $\mathbf{1 0 \%} \mathbf{C S}$ & $\mathbf{C S - f r e e ~}$ \\
\hline Control & $2.7 \pm 0.4$ & $22.7 \pm 2.5$ \\
H-89, 10 & $3.0 \pm 0.4$ & $24.8 \pm 3.0$ \\
KT 5720, 5 & $2.8 \pm 0.5$ & $23.6 \pm 3.0$ \\
H-8, 10 & $3.3 \pm 0.6$ & $25.0 \pm 2.4$ \\
Forskolin, 10 & $2.0 \pm 0.3$ & $5.9 \pm 0.8^{\star \star *}$ \\
H-89+forskolin & $2.6 \pm 0.4$ & $12.0 \pm 1.6^{\star *}$ \\
KT 5720+forskolin & $3.5 \pm 0.7$ & $15.7 \pm 2.0^{*}$ \\
H-8+forskolin & $2.2 \pm 0.2$ & $20.7 \pm 2.6$ \\
\hline
\end{tabular}

Cells were preincubated with $\mathrm{H}-89$, KT 5720 and $\mathrm{H}-8$ in the presence of $10 \%$ calf serum (CS) for $1 \mathrm{~h}$. Then, the medium was aspirated and cells were incubated for the next $6 \mathrm{~h}$ with the same compounds in the presence or absence of calf serum and forskolin. Data from three experiments performed in quadruplicate are shown as means \pm S.E. ${ }^{*} P<0.05,{ }^{* \star} P<0.01$ and ${ }^{* *} P<0.001$ as compared with the controls respectively

a)

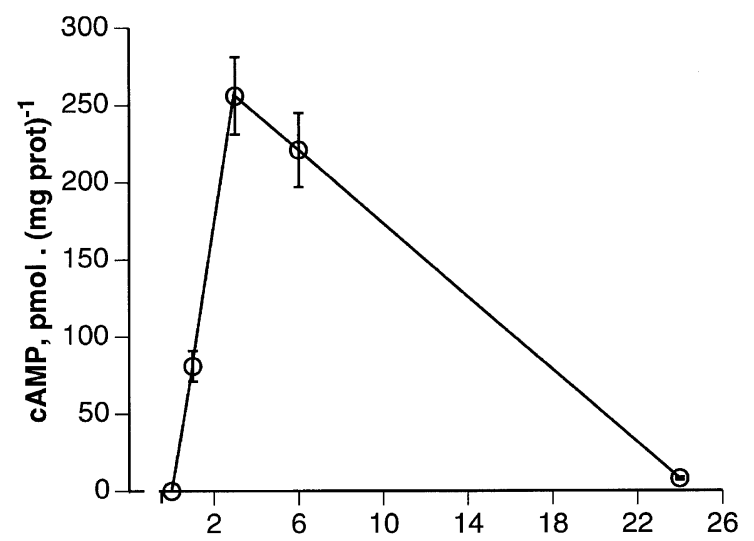

b)

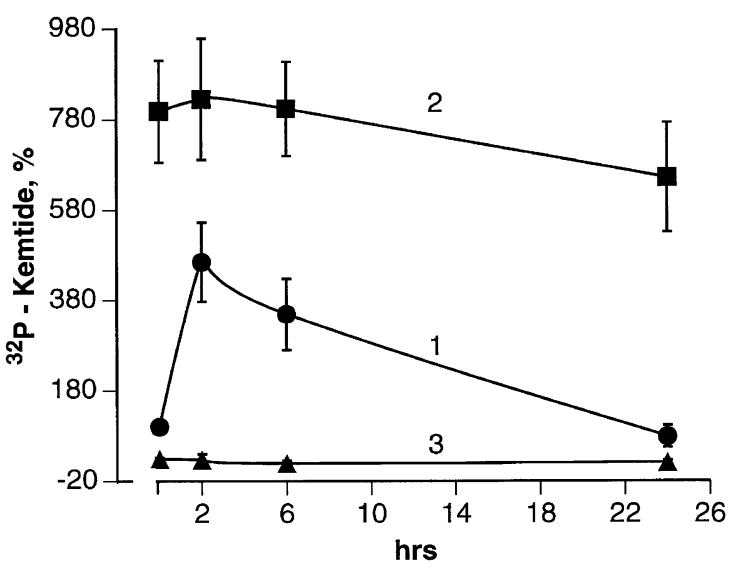

Figure 7 Kinetics of modulation of intracellular CAMP content (a) and protein kinase A activity (b) by forskolin in VSMC. PKA activity was measured in the absence (curve 1) or in the presence of $0.1 \mathrm{mM}$ cAMP (curve 2) and $0.1 \mathrm{mM}$ cAMP $+10 \mu \mathrm{M}$ PKI (curve 3 ). The radioactivity of PKA substrate, Kemptide, in control (forskolin-untreated cells) measured in the absence of cAMP and PKI was taken as $100 \%$. Data from experiments performed in triplicate are shown as means \pm S.E 
$10 \%$ CS CS-free

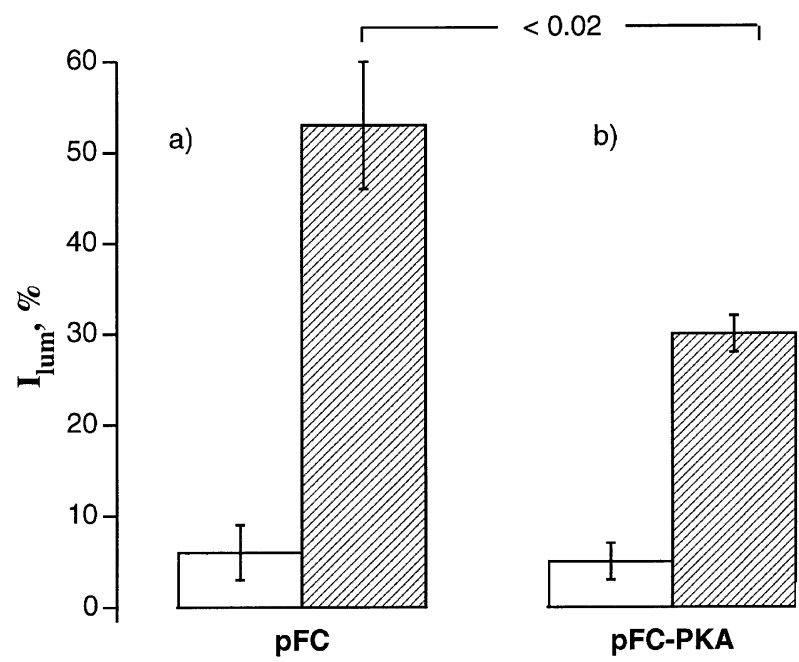

Figure 8 Effect of PKA on apoptosis in VSMC-E1A. Cells were cotransfected with luciferase and $\mathrm{pFC}$ empty vector (a) or with $\mathrm{pFC}$ containing catalytic subunit of PKA (b) as described in the Materials and Methods section. In $36 \mathrm{~h}$, cells were washed and incubated in the presence of $10 \%$ calf serum (CS) or in CS-free DMEM. In $6 \mathrm{~h}$, medium was transferred into tubes, centrifuged $(800 \times g, 5 \mathrm{~min})$ and pellet as well as cells remaining on plates were washed twice with PBS. Then, cells were lysed in $250 \mu \mathrm{l}$ of Mammalian Protein Extraction Reagent (M-PER ${ }^{\mathrm{TM}}$ Pierce, Rockford, IL, USA), cleared by centrifugation and $20 \mu$ l of lysates were used for the measurement of luminescence in cells from medium (I lum $)$ and from plates. The total values of luminescence of detached and attached cells were taken as $100 \%$. Data from experiment performed in triplicate are shown as means \pm S.E forskolin (Figure 9D). This feature of VSMC-MYC is probably related to the different organization of the cytoskeleton network caused by fivefold depletion of these cells with actin. ${ }^{12}$ However, despite the lack of cytoskeleton reorganization, similarly to VSMC and VSMC-E1A, forskolin still prevented chromatin cleavage in serum-deprived VSMCMYC (Table 2). Neither acute nor chronic exposure to forskolin modified phosphorylation of ERK1 (p42) and ERK2 (p44) MAP kinases (Figure 10).

\section{Discussion}

Data obtained in this study show for the first time that activation of CAMP signaling transiently inhibits apoptosis in serum-deprived VSMC. In contrast to CAMP, elevation of intracellular cGMP caused by $8-\mathrm{Br}-\mathrm{cGMP}$ or ANP did not affect VSMC apoptosis. The addition of nitroprusside for $6 \mathrm{~h}$ slightly potentiated chromatin cleavage in VSMC-E1A (Table 2). Recently, it has been reported that 48-96 h treatment of VSMC from the rat and human aorta with NO donors including nitroprusside leads to accumulation of apoptotic cells. ${ }^{36,37}$ However, this effect was caused by cGMP-independent activation of the expression of Fas-ligand receptor ${ }^{36}$, reduction of free radical scavengers ${ }^{37}$ or expression of c-myc and p53. ${ }^{38}$

The antiapoptotic time window observed in forskolintreated VSMC coincided with the kinetics of CAMP production and activation of PKA (Figures 6 and 7). Inhibition of apoptosis by forskolin was also diminished in the presence of the inhibitors of PKA, H-89 and KT-5720, and was insensitive to the PKG inhibitor, $\mathrm{H}-8$ (Table 4). Moreover, similar to CAMP-rising compounds, transfection of VSMC-E1A with catalytic subunit of PKA diminished

\section{VSMC}
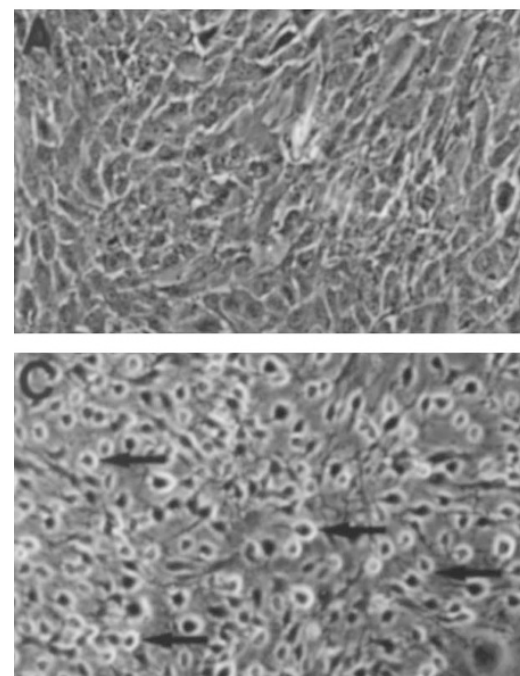

VSMC-MYC

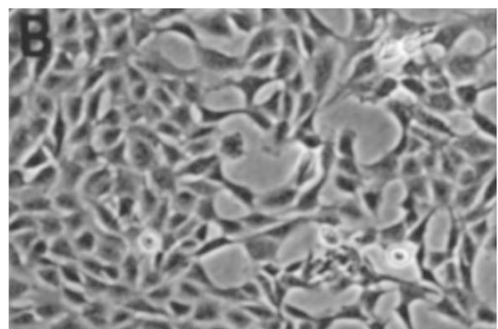

control

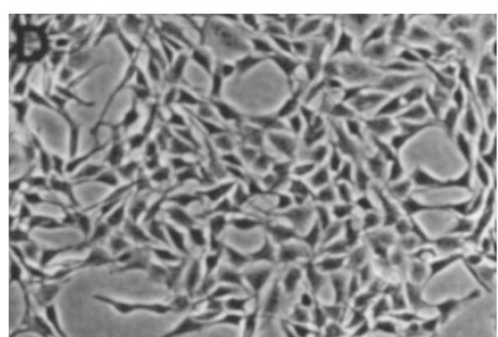

Figure 9 Phase-contrast microscopy of control (A, B) and forskolin-treated (C, D) non-transfected cells (VSMC; A, C) and c-myc-transfected cells (VSMC-MYC; B, D) 
A

$\alpha$ ERK

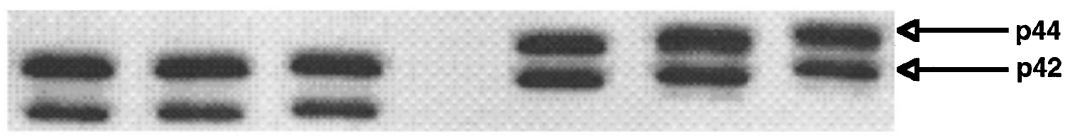

B

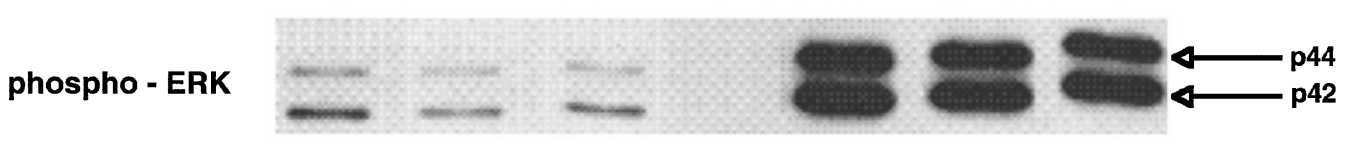

$\begin{array}{lcc}0 & 0.5 & 24 \\ \text { CS - free }\end{array}$

\begin{tabular}{lcc}
0 & 0.5 & 24 \\
\hline & $+10 \%$ CS
\end{tabular}

Addition of forskolin (hrs)

Figure 10 Phosphorylation of MAP kinase ( $\alpha$ ERK) in the presence and absence of calf serum and forskolin. VSMC were serum starved for 2 days in DMEM containing $0.1 \%$ BSA. In some of the samples, forskolin was added for $24 \mathrm{~h}$ or during the last $0.5 \mathrm{~h}$ of preincubation as indicated. Then, these media were aspirated and DMEM with or without $10 \%$ calf serum was added for an additional $10 \mathrm{~min}$. MAPK phosphorylation was determined by gel retardation using anti-p42 ERK antibodies (A), or by immunoblotting with phospho-specific anti-p42/p44 ERK antibodies (B)

Table 5 Effect of forskolin on apoptosis in VSMC-E1A in the presence of modulators of cytoskeleton assembly

\begin{tabular}{lcc}
\hline & \multicolumn{2}{c}{ Chromatin fragments, \% } \\
Additions, $\mu \mathbf{M}$ & $\mathbf{1 0 \%} \mathbf{C S}$ & $\mathbf{C S - f r e e}$ \\
\hline Control & $3.1 \pm 0.6$ & $25.9 \pm 3.5$ \\
Cytochalasin B, 10 & $2.9 \pm 0.3$ & $22.7 \pm 2.8$ \\
Colchicine, 40 & $3.3 \pm 0.6$ & $21.5 \pm 4.3$ \\
Forskolin, 10 & $1.9 \pm 0.4$ & $6.5 \pm 0.8^{\star}$ \\
Cytochalasin B+forskolin & $2.1 \pm 0.3$ & $6.3 \pm 0.5^{\star}$ \\
Colchicine+forskolin & $1.8 \pm 0.5$ & $7.6 \pm 0.9^{\star}$ \\
\hline
\end{tabular}

Cells were preincubated with cytochalasin B or colchicine in the presence of $10 \%$ calf serum (CS) for $30 \mathrm{~min}$. Then, the medium was aspirated and cells were incubated for the next $6 \mathrm{~h}$ with the same compounds in the presence or absence of calf serum and forskolin. Data from two experiments performed in quadruplicate are shown as mean \pm S.E. ${ }^{\star} P<0.001$ as compared to the controls

apoptosis triggered by serum withdrawal (Figure 8). Considering this, it may be concluded that the antiapoptotic action of the CAMP signaling pathway is mediated via activation of PKA.

In the majority of cells studied so far, activation of cysteine proteases of the caspase superfamily is viewed as 'a point of no return' in the development of apoptotic machinery. ${ }^{39}$ However, data on the involvement of caspases in VSMC apoptosis are limited to a few publications showing cleavage of procaspase-3 after $6 \mathrm{~h}$ treatment of VSMC-E1A in serum-deprived medium ${ }^{40}$ or after chronic treatment of VSMC with NO donors. ${ }^{38}$ Here, we report that after $6 \mathrm{~h}$ serum deprivation of VSMC-E1A, caspase-3 activity was enhanced by tenfold. Both the baseline activity of this enzyme and its increment triggered by serum deprivation were sharply decreased in forskolintreated cells (Table 3 ). We did not observe any modulation of caspase-3 activity in VSMC-E1A lysate by additions of
cAMP $(0.5 \mathrm{mM})$ and catalytic subunit of protein kinase A $(1 \mathrm{U} / \mathrm{ml}$ ) in the presence of $0.5 \mathrm{mM}$ ATP (data not shown). These results strongly suggest that the CAMP/PKAsensitive step of development of the apoptotic machinery in VSMC is located upstream of caspase-3.

Several mechanisms can be proposed by the analysis of data on the antiapoptotic action of activators of cAMP signaling in VSMC. Thus, the CAMP-induced delay of apoptosis may be caused by transient reorganization of cytoskeleton network seen in VSMC treated with activators of CAMP signaling. ${ }^{29,31-33}$ However, this hypothesis should be probably ruled out because of the lack of effect of modulators of cytoskeleton assembly on VSMC apoptosis in the absence or presence of forskolin (Table 5) and the same level of inhibition of apoptosis in VSMC-MYC by forskolin despite the lack of forskolin-induced cytoskeleton reorganization in these cells (Figure 9).

Induction of apoptosis by c-myc is linked with the continuation of cell cycling in the absence of growth factors. ${ }^{12}$ Considering this, it may be assumed that inhibition of apoptosis by CAMP may be mediated by modulation of MAPK signaling cascade involved in the regulation of VSMC proliferation and cell cycle progression. ${ }^{41}$ This hypothesis is based on the transient PKAdependent suppression by CAMP of Ras-dependent activation of MAPKK kinase Raf-1 observed in several fibroblast cell lines. ${ }^{42}$ Recently, however, it was shown that in contrast to these observations, angiotensin II-induced ERK1/ERK2 phosphorylation and MAPK activity are not affected by 30 min preincubation of VSMC with forskolin, ${ }^{43}$ indicating the lack of involvement of this signaling pathway in angiotensin Il-induced protein synthesis and hypertrophy. The data obtained in the present study demonstrate that neither acute $(30 \mathrm{~min})$ nor chronic $(24 \mathrm{~h})$ treatment of VSMC with forskolin significantly affects the baseline content and phosphorylation of ERK1/ERK2 as well as 
the induction of phosphorylation of these proteins by brief exposure to calf serum (Figure 10). These results show that the MAPK cascade, terminated by activation of ERK1/ ERK2, is not involved in the transient inhibition of apoptosis by forskolin.

In conclusion, the results obtained in this investigation show that activation of cAMP signaling transiently inhibits apoptosis in VSMC. This inhibitory effect is mediated by PKA, is independent of cAMP-induced cytoskeleton reorganization and $M A P K E R K 1 / 2$, and affects a step upstream of caspase-3. The role of other members of MAPK signaling cascade, including the stress-regulated MAPK p38 and JNK, as well as bcl-2, p53 and cyclindependent kinases and phosphatases subjected to phosphorylation-dephosphorylation cycle in the inhibition of VSMC apoptosis by CAMP should be examined further.

\section{Materials and Methods}

\section{Cultured VSMC}

VSMC were obtained by explant methods from aortas of 10-13-weekold male Brown Norway (BN.1x) rats in accordance with previouslydescribed methods. ${ }^{44}$ VSMC-MYC and VSMC-E1A constitutively expressing $c-m y c$ and $E 1 A$-adenoviral protein $^{8,12}$ were kindly provided by Dr. MR Bennett (University of Cambridge, UK). VSMC morphology was evaluated by phase contrast microscopy without preliminary fixation. Micrographs were produced using a Nikon phase contrast microscope and fluorescent microscope (Leica) at $\times 100$ magnification.

\section{Cell transfection}

VSMC-E1A growing in 12-well plates were co-transfected with $0.5 \mu \mathrm{g} /$ well luciferase expression vector (Promega, Madison, WI, USA) and $1.5 \mu \mathrm{g} /$ well of empty $\mathrm{pFC}$ vector or vector containing catalytic subunit of protein kinase A (pFC-PKA, Stratagene, La Jolla, CA, USA). Transfection was performed for $3 \mathrm{~h}$ in the presence of $5 \%$ calf serum using LipofectAMINEPLUS reagent (Gibco, BRL) following standard manufacturer's protocol. Then, medium was aspirated and cells were incubated during $36 \mathrm{~h}$ in DMEM containing $10 \%$ calf serum. The efficiency of transfection was estimated by analysis of luciferase luminescence using Luciferase Assay Reagent (Promega). For more details see Figure 8.

\section{Chromatin cleavage assay}

Previously-described method ${ }^{45}$ with minor modifications listed below was used in this study. Cells in 24-well dishes were supplied with $1 \mathrm{ml}$ of DMEM containing $10 \%$ calf serum and $1 \mu \mathrm{Ci} / \mathrm{ml}\left[{ }^{3} \mathrm{H}\right]$-thymidine. After $24 \mathrm{~h}$, they were washed with $2 \times 2 \mathrm{ml}$ of DMEM and incubated in DMEM with $10 \% \mathrm{CS}$. In $48 \mathrm{~h}$, the cells were washed again and incubated with DMEM containing $10 \%$ calf serum or with serumdepleted DMEM. At the time intervals indicated in figure and table legends, the medium was transferred and centrifuged at $900 \times g$ for $10 \mathrm{~min}$. The supernatant was then transferred for the measurement of radioactivity (fraction $\mathrm{F}_{1}$ ), and the cell pellet was treated for $15 \mathrm{~min}$ with ice-cold lysed buffer (10 mM EDTA, $10 \mathrm{mM}$ Tris- $\mathrm{HCl}, 0.5 \%$ Triton $\mathrm{X}-100(\mathrm{pH} 8.0))$. Cells remaining in wells were treated with lysed buffer under the same protocol. Next, the cell lysates were combined, sedimented (12000 r.p.m., $10 \mathrm{~min}$ ) and the supernatant was transferred for the measurement of radioactivity (fraction $F_{2}$ ). The remaining radioactivity from the pellets and wells was extracted with $1 \%$ SDS/4 mM EDTA mixture (fraction $\mathrm{F}_{3}$ ). Radioactivity of samples was measured in a liquid scintillation spectrometer, and the relative content of intracellular chromatin fragments $\left(F_{2} \times\left(F_{1}+F_{2}+\right.\right.$ $\left.F_{3}\right)^{-1} \times 100 \%$ ) was determined as a percentage of the total amount of ${ }^{3} \mathrm{H}$-labeled DNA.

\section{DNA isolation and $3^{\prime}$ end labeling}

The incubation medium was aspirated, and cells seeded in $75 \mathrm{~cm}^{2}$ flasks were treated with $4 \mathrm{ml}$ of lysis buffer containing $50 \mathrm{mM}$ Tris- $\mathrm{HCl}$, $20 \mathrm{mM}$ EDTA (pH 8.0), 0.5\% SDS and $500 \mu \mathrm{g} / \mathrm{ml}$ proteinase $\mathrm{K}$. The lysate was then incubated at $50^{\circ} \mathrm{C}$ for $3 \mathrm{~h}$ and additionally for $1 \mathrm{~h}$ at $37^{\circ} \mathrm{C}$ in the presence of $250 \mu \mathrm{g} / \mathrm{ml}$ RNase A. After phenol-chloroform extraction, DNA was precipitated by the addition of a mixture containing $0.5 \mathrm{M}$ potassium acetate and ethanol $(1: 2 \mathrm{v}: \mathrm{v})$. The precipitate was resuspended in water, and DNA was estimated by spectrophotometry at $260 \mathrm{~nm}$. 3'-end DNA labeling with terminal deoxynucleotidyl transferase (tdt) was performed as described in detail previously. ${ }^{1}$ Briefly, $1 \mu \mathrm{g}$ of DNA was mixed with a solution, containing $2 \mathrm{mM} \mathrm{CoCl}, 0.2 \mathrm{mM}$ dithiothreitol, $100 \mathrm{mM}$ potassium cacodilate, $0.5 \mathrm{mM}\left[{ }^{32} \mathrm{P}\right]-\mathrm{dCTP}(3000 \mathrm{Ci} / \mathrm{mmol})$ and $15 \mathrm{U} / \mu \mathrm{l}$ td for a final volume of $20 \mu \mathrm{l}$. After $1 \mathrm{~h}$ incubation at $37^{\circ} \mathrm{C}$, aliquots containing $0.2 \mu \mathrm{g}$ DNA were loaded on $1.5 \%$ agarose gel, run at $100 \mathrm{~V}$ for $3-4 \mathrm{~h}$, transferred onto a nylon membrane (Hybond $\mathrm{N}+$, Amersham), and analyzed with a Phosphorlmager (Molecular Dynamics, CA, USA).

\section{Staining with Hoechst 33258}

To visualize apoptotic nucleus, VSMC-E1A cells seeded in 6-well plates were treated for $8 \mathrm{~h}$ in serum-deprived medium. Then, medium was transferred into tubes, detached cells were sedimented (1200 r.p.m., $5 \mathrm{~min}$ ), washed twice with PBS, stained for $10 \mathrm{~min}$ with Hanks' balanced salt solution containing $50 \mathrm{ng} / \mathrm{ml}$ Hoechst 33258 , washed twice again and transferred on Superfrost/Plus slides (Fisher, Neopon, ON, Canada). Cells remaining on plates were washed with PBS, stained for 10 min with the same Hoechst 33258 solution and washed with PBS.

\section{Detection of phosphatidylserine on the outer leaflet of apoptotic cells}

VSMC-EIA seeded in $25 \mathrm{~cm}^{2}$ flasks were subjected to $6 \mathrm{~h}$ of serum deprivation. Then, medium was aspirated and cells were treated during $5 \mathrm{~min}$ at $37^{\circ} \mathrm{C}$ with $0.05 \%$ trypsin (Gibco Laboratories) in $\mathrm{Ca}^{2+}$. and $\mathrm{Mg}^{2+}$-free Dulbecco's phosphate buffered saline. Trypsinization was terminated by the addition of $10 \%$ calf serum and suspension was combined with previously aspirated medium. The cells were sedimented (1200 r.p.m., $8 \mathrm{~min}, 4^{\circ} \mathrm{C}$ ), washed twice with ice-cold medium A containing $140 \mathrm{mM} \mathrm{NaCl}, 5 \mathrm{mM} \mathrm{KCl}, 1 \mathrm{mM} \mathrm{MgCl}_{2}, 1 \mathrm{mM}$ $\mathrm{CaCl}_{2}, 5 \mathrm{mM}$ D-glucose and $20 \mathrm{mM}$ HEPES-Tris ( $\mathrm{pH} 7.4$ ), counted, and the volume was adjusted with the same medium to reach a final concentration $10^{7}$ cells $/ \mathrm{ml}$. Aliquots containing $10^{6}$ cells were washed with PBS and labeled with annexin-V-Fluos (Boehringer, Mannheim, Indianapolis, IN, USA) in medium containing $140 \mathrm{mM} \mathrm{NaCl}, 5 \mathrm{mM}$ $\mathrm{CaCl}_{2}$ and $10 \mathrm{mM}$ HEPES-NaOH ( $\mathrm{pH} 7.4$ ), following the manufacturer's instructions. The relative amount of annexin-labeled cells was determined on a flow cytometer (Becton-Dickinson, Franklin Lakes, 
NJ, USA) at excitation and emission wavelengths 488 and $515 \mathrm{~nm}$, respectively. To adjust cytometer for non-specific annexin binding, $5 \mathrm{mM} \mathrm{CaCl}_{2}$ was substituted with $0.2 \mathrm{mM} \mathrm{EGTA}$.

\section{Caspase activity}

Cells growing in $20 \mathrm{~cm}^{2}$ plates were transferred onto ice, scratched with a rubber policeman, sedimented at $1000 \times g$ for $5 \mathrm{~min}$ at $4{ }^{\circ} \mathrm{C}$, and washed twice with medium containing $140 \mathrm{mM} \mathrm{NaCl}, 5 \mathrm{mM} \mathrm{KCl}, 1 \mathrm{mM}$ $\mathrm{MgCl}_{2}, 1 \mathrm{mM} \mathrm{CaCl}$, $5 \mathrm{mM}$ glucose, $20 \mathrm{mM} \mathrm{HEPES}$-Tris buffer $(\mathrm{pH} 7.4)$. The pellet was frozen in liquid nitrogen and kept at $-80^{\circ} \mathrm{C}$. Before the measurement of caspase activity, it was resuspended in $0.5 \mathrm{ml}$ of ice cold lysate buffer A containing $50 \mathrm{mM}$ Tris- $\mathrm{HCl}, 1 \mathrm{mM}$ EGTA, $5 \mathrm{mM} \mathrm{MgCl} \mathrm{Mn}_{2}$ and $0.1 \%$ CHAPS (pH 7.4), and kept on ice. To measure caspase activity, $50 \mu \mathrm{l}$ of cell lysate were added to $450 \mu \mathrm{l}$ of lysate buffer A containing $1 \mathrm{mM}$ dithiothreitol, $40 \mu \mathrm{M}$ DEVD-AMC with or without $1 \mu \mathrm{M}$ of the caspase-3 inhibitor AcDEVD-CHO. After $2 \mathrm{~h}$ of incubation at $37^{\circ} \mathrm{C}$, the reaction was stopped by transfer of $200 \mu \mathrm{l}$ of protein suspension into $600 \mu \mathrm{l}$ of $0.4 \mathrm{M}$ glycine$\mathrm{NaOH}$ buffer $(\mathrm{pH} 10.0)$. Before measurement, the samples were diluted by fourfold with water, and fluorescence was measured at $\lambda_{\mathrm{ex}}=365 \mathrm{~nm}$ and $\lambda_{\mathrm{em}}=465 \mathrm{~nm}$ (slits 4 and $20 \mathrm{~nm}$, respectively). The fluorescent signal was calibrated with $A M C$ in the range from $0.01-$ $0.3 \mu \mathrm{M}$. Protein content in the cell lysate was measured by the Bradford method. Caspase-3 activity was calculated as a difference of DEVDase activity in the absence and presence of Ac-DEVD-CHO.

\section{cAMP content}

Cells seeded in 12-well plates were incubated in DMEM containing $10 \%$ calf serum without or with forskolin. At the time intervals indicated in Figure 3, the medium was aspirated, the cells were washed with $2 \times 2 \mathrm{ml}$ of medium containing $150 \mathrm{mM} \mathrm{NaCl}, 20 \mathrm{mM}$ HEPES-Tris buffer, $\mathrm{pH} 7.4$, at $20^{\circ} \mathrm{C}$, and intracellular CAMP was extracted with $1 \mathrm{ml}$ of $1 \mathrm{~N}$ perchloric acid. CAMP content was determined by radioimmunoassay. ${ }^{46}$ Protein content was measured by the Lowry method.

\section{Protein kinase A activity}

Digitonin-permeabilized VSMC loaded with a PKA specific substrate Kemptide were used in this study. ${ }^{47}$ Control and forskolin-treated cells seeded in 6-well plates were washed once with PBS and incubated for $10 \mathrm{~min}$ in $1 \mathrm{ml}$ of medium containing $140 \mathrm{mM} \mathrm{NaCl}, 5 \mathrm{mM} \mathrm{MgCl}$, $0.2 \mathrm{mM}$ EGTA, $0.1 \mathrm{mM}\left[{ }^{32} \mathrm{P}-\gamma\right]$-ATP ( 700 c.p.m./pmol), $0.1 \mathrm{mM}$ Kemptide, $0.04 \%$ digitonin $\pm 0.1 \mathrm{mM}$ cAMP and $10 \mu \mathrm{M}$ PKA inhibitor (PKI 6-22 amide). This medium was aspirated, cells were treated with $0.5 \mathrm{ml}$ of $10 \%$ trichloroacetic acid, cell lysate was centrifuged (12000 r.p.m., $10 \mathrm{~min}, 2^{\circ} \mathrm{C}$ ) and supernatant was transferred onto the manifold, holding 12 Whatman P811 disks which were washed four times with $70 \mathrm{mM}$ phosphoric acid, once with absolute ethanol and counted. ${ }^{48}$

\section{MAPK phosphorylation}

Serum-starved VSMC grown in 6-well plates were preincubated with forskolin, stimulated with $10 \%$ calf serum for 10 min, washed twice with ice-cold phosphate-buffered saline and lysed in $150 \mathrm{ml}$ of buffer containing $25 \mathrm{mM}$ HEPES-NaOH (pH 7.5), $150 \mathrm{mM} \mathrm{NaCl}, 1.5 \mathrm{mM}$ $\mathrm{MgCl}_{2}, 1 \mathrm{mM}$ EGTA, 10\% Triton X-100, 1 mM phenylmethylsulphonyl fluoride, $1 \mu \mathrm{g} / \mathrm{ml}$ leupetin, $1 \mu \mathrm{g} / \mathrm{ml}$ aprotinin, $200 \mu \mathrm{M}$ Na-orthovanadate and $1 \mathrm{mM} \mathrm{NaF}$. The lysed cells were scraped, centrifuged at 14000 r.p.m. for $20 \mathrm{~min}$, and an equal volume of clear lysates containing $20 \mu \mathrm{g}$ of protein was applied on $10 \%$ polyacrylamide gel, followed by electrophoresis and transfer to Immobilon-P membrane (Millipore Corp., Bedford, MA, USA). Phosphorylation of p42/p44 MAPK was determined by Western blot analysis with antibodies against phospho-ERK, following the manufacturer's instructions and documenting the electrophoretic mobility shift of phosphorylated MAPK, using anti-p42 ERK antibodies. Protein content in the cell lysate was measured by the Bradford method.

\section{Chemicals}

$\left[{ }^{3} \mathrm{H}\right]$-thymidine - Amersham (Mississauga, ON, Canada); [ $\left.{ }^{32} \mathrm{P}-\gamma\right]$-ATP - Amersham (Cleveland, OH, USA); H-8, H-89, KT 5720, cholera toxin, protein kinase $A$ inhibitor (PKI 6-22 amide) - Calbiochem Novabiochem (La Jolla, CA, USA); sodium nitroprusside, L-NAME RBI (Natick, MA, USA); cAMP, 8-Br-cAMP, 8-Br-cGMP, catalytic subunit of protein kinase A, Kemptide - Sigma (St. Louis, MO, USA); phospho-ERK antibodies - New England Biolab Inc. (Beverly, MA, USA); 7-amino-4-methylcoumarin (AMC) - Molecular Probes (Eugene, OR, USA); DEVD-AMC (N-acetyl-Asp-Glu-Val-Asp-AMC), DEVD-CHO - BIOMOL Research Laboratories (Plymouth Meeting, PA, USA). Anti-p42 ERK antibodies were kindly provided by Dr. Michael J Dunn (Medical College of Wisconsin, Milwaukee, WI, USA). The remaining chemicals were obtained from Sigma, Gibco BRL (Gaithersburg, MD, USA) and Anachemia (Montreal, QC, Canada).

\section{Acknowledgements}

This work was supported by grants from the Medical Research Council of Canada (MT-10803) and Bayer Canada. The technical assistance of Monique Poirier and Suzanne Cossette and the editorial help of Ovid Da Silva are appreciated.

\section{References}

1. Hamet P, Richard L, Dam TV, Teiger E, Orlov SN, Gaboury L, Gossard F and Tremblay J (1995) Apoptosis in target organs of hypertension. Hypertension 26: 642-648

2. Hamet P, DeBlois D, Dam T-V, Orlov SN and Tremblay J (1996) Apoptosis in vascular smooth muscle. Can. J. Physiol. Pharmacol. 47: 124-129

3. Han DKM, Haudenschild CC, Hong MK, Tinkle BT, Leon MB and Liau G (1995) Evidence for apoptosis in human atherogenesis and in rat vascular injury model. Am. J. Pathol. 147: 267-277

4. Bennett MR, Evan GI and Schwartz SM (1995) Apoptosis of human vascular smooth muscle cells derived from normal vessels and coronary atherosclerotic plaques. J. Clin. Invest. 95: 2266-2274

5. DeBlois D, Tea B-S, Dam T-V, Tremblay J and Hamet P (1997) Smooth muscle apoptosis during vascular regression in spontaneously hypertensive rats. Hypertension 29: 340-349

6. Jackson CL and Schwartz SM (1992) Pharmacology of smooth muscle cell replication. Hypertension 20: 713-736

7. Lee RM, Owens GK, Scott-Burden T, Head RJ, Mulvany MJ and Schiffrin EL (1995) Pathophysiology of smooth muscle in hypertension. Can. J. Physiol. Pharmacol. 73: 574-584

8. Bennett MR, Evan Gl and Schwartz SM (1995) Apoptosis of rat vascular smooth muscle cells is regulated by p53-dependent and -independent pathways. Circ. Res. 77: 266-273

9. Bennett MR, Macdonald K, Chan S-W, Luzio JP, Simari R and Weissberg P (1998) Cell surface trafficking of Fas: a rapid mechanism of p53-mediated apoptosis. Science 282: 290-293 
10. Ares MPS, Pornares MI, Thyberg J, Junttiberggren L, Berggren PO, Diczfalusy U, Kallin B, Bjorkhem I, Orrenius S and Nilsson J (1997) $\mathrm{Ca}^{2+}$ channel blockers verapamil and nifedipine inhibit apoptosis induced by 25-hydroxycholesterol in human aortic smooth muscle cells. J. Lipid Res. 38: 2049-2061

11. Geng Y-J, Henderson LE, Levesque EB, Muszynski M and Libby $P$ (1997) Fas is expressed in human atherosclerotic intima and promotes apoptosis of cytokinine-primed human vascular smooth muscle cells. Arterioscler. Thromb. Vasc. Biol. 17: 2200-2208

12. BennettMR, Evan Gland Newby AC (1994)Deregulated expression of the c-myc oncogene abolishes inhibition of proliferation of rat vascular smooth muscle cells by serum reduction, interferon- $\gamma$, heparin, and cyclic nucleotide analogues and induces apoptosis. Circ. Res. 74: 525-536

13. Ito T, Deng X, Carr B and May WS (1997) Bcl-2 phosphorylation required for antiapoptotsis function. J. Biol. Chem. 272: 11671-11673

14. Yan Y, Shay JW, Wright WE and Mumby MC (1997) Inhibition of protein phosphatase activity induces p53-dependent apoptosis in the absence of p53 transactivation. J. Biol. Chem. 272: 15220-15226

15. Horiuchi M, Hayashida W, Kambe T, Yamada T and Dzau V (1997) Angiotensin type 2 receptor dephosphorylates bcl-2 by activating protein kinase phosphatase-1 and induces apaoptosis. J. Biol. Chem. 272: $19022-19026$

16. Lanotte M, Riviere JB, Hermouet S, Houge G, Vitermyr OK, Gjersen BT and Doskeland SO (1991) Programmed cell death (apoptosis) is induced rapidly and with positive cooperativity by activation of cyclic adenosine monophosphatekinase I in a myeloid leukemia cell line. J. Cell. Physiol. 146: 73-80

17. Aharoni D, Dantes A, Oren M and Amsterdam A (1995) cAMP-mediated signals as determinants for apoptosis in primary granulosa cells. Exp. Cell Res. 218: $271-282$

18. Kizaki H, Suzuki K, Takaduma T and Ishimura Y (1990) Adenosine receptormediated accumulation of cyclic AMP-induced T-lymphocyte death through internucleosomal DNA cleavage. J. Biol. Chem. 265: 5280-5284

19. Yasutomi D, Odaka C, Saito S, Nizeki H, Kizaki H and Takaduma T (1992) Inhibition of programmed cell death by cyclosporin A: preferential blocking of cell death induced by signals via TCR/CD3 complex and its mode of action. Immunology 77: 68-74

20. Suzuki K, Takaduma T and Kizaki H (1991) Modulation of thymocyte apoptosis by isoproterenol and prostagalndin $\mathrm{E}_{2}$. Cell. Immunol. 134: 235-240

21. Pratt RM and Martin GR (1975) Epithelial cell death and cyclic AMP increase during palatal development. Proc. Natl. Acad. Sci. USA 72: 874-877

22. De A, Boyadijeva I, Pastoric M, Reddy BV and Sarkar DK (1994) Cyclic AMP and ethanol interact to control apoptosis and differentiation in hypothalamic $\beta$ endorphin neurons. J. Biol. Chem. 269: 26697-26705

23. Galli G, Meucci O, Scorziello A, Werge TM, Calissano P and Schettini G (1995) Apoptosis in cerebellar granule cells is blocked by high $\mathrm{KCl}$, forskolin, and IGF-1 through distinct mechanisms of action: the involvement of intracellular calcium and RNA synthesis. J. Neurosci. 15: 1172-1179

24. Parvathenani LK, Buescher ES, Chacon-Cruz E and Beebe SJ (1998) Type cAMP-dependent protein kinase delays apoptosis in human neutrophils at a site upstream of caspase-3. J. Biol. Chem. 273: 6736-6743

25. Lee M, Liou M, Yang Y-F and Lai M-Z (1993) cAMP analogue prevent activationinduced apoptosis of T cell hybridomas. J. Immunol. 151: 5208-5217

26. Sciorati C, Rovere P, Ferrarini M, Helta S, Manfredi AA and Clementi E (1997) Autocrine nitric oxide modulates CD95-induced apoptosis in $\gamma-\delta$ T lymphocytes. J. Biol. Chem. 272: 23211-23215

27. Jun CD, Pae HO, Yoo JC, Kwak HJ, Park RK and Chung HT (1998) Cyclic adenosine monophosphate inhibits nitric oxide-induced apoptosis in human leukemic HL-60 cells. Cell. Immunol. 183: 13-21

28. Wu C-F, Bishopric NH and Pratt RE (1997) Atrial natriuretic peptide induced apoptosis in neonatal rat cardiac myocytes. J. Biol. Chem. 272: 14860-14866

29. Orlov SN, Tremblay J and Hamet $\mathrm{P}$ (1995) Altered $\beta$-adrenergic regulation of $\mathrm{Na}$ $\mathrm{K}-\mathrm{Cl}$ cotransport in cultured smooth muscle cells from the aorta of spontaneously hypertensive rats. Am. J. Hypertens. 8: 739-747
30. Jonzon B, Nilsson J and Fredholm B (1985) Adenosine receptor-mediated changes in cyclic AMP production and DNA synthesis in cultured arterial smooth muscle cells. J. Cell Physiol. 124: 451-456

31. Smith JB (1984) $\beta$-Adrenergic stimulation inhibits calcium efflux and alters the morphology of cultured arterial muscle cells. J. Cell Physiol. 121: 375-382

32. Chaldakov GN, Nabika T, Nara T and Yamori Y (1989) Cyclic AMP- and cytocholasin B-induced arborization in cultured aortic smooth muscle cells: its cytopharmacological characterization. Cell Tissue Res. 255: 435-442

33. Orlov SN, Tremblay J and Hamet P (1996) Cell volume in vascular smooth muscle is regulated by bumetanide-sensitive ion transport. Am. J. Physiol. 270: C1388-C1397

34. Chijiwa T, Mishima A, Hagiwara M, Sano M, Hayashi K, Inoue T, Naito K, Toshioka T and Hidaka H (1990) Inhibition of forskolin-induced neurite outgrowth and protein phosphorylation by a newly synthesized selective inhibitor of cyclic AMP-dependent protein kinase, N-[2-(p-bromocinnamylamino)ethyl]-5-isoquinolinesulfonamide (H-89), of PC12D pheochromacytoma cells. J. Biol. Chem. 265: $5267-5272$

35. Hagiwara M, Inagaki M and Hidaka H (1987) Specific binding of a novel compound, N-[2-(methylamino)ethyl]-5-isiquinolinesulfonamide $(\mathrm{H}-8)$ to the active site of CAMP-dependent protein kinase. Mol. Pharmacol. 31: 523-528

36. Fukuo K, Hata S, Suhara T, Nakahashi T, Shinto Y, Tsujimoto S and Ogihara T (1996) Nitric oxide induces upregulation of Fas and apoptosis in vascular smooth muscle. Hypertension 27: 823-826

37. Zhao Z, Francis CE, Welch G, Loscalzo J and Ravid K (1997) Reduced gluthatione prevents nitric oxide-induced apoptosis in vascular smooth muscle cells. Biochim. Biophys. Acta 1359: 143-152

38. Nishio $E$ and Watanabe $Y$ (1998) NO induced apoptosis accompanying the change of oncoprotein expression and the activation of CPP32 protease. Life Sci. 62: $239-245$

39. Thornberry NA and Lazebnik Y (1998) Caspases: enemies within. Science 281: $1312-1316$

40. Champagne M-J, Dumas P, Orlov SN, Bennett MR, Hamet P and Tremblay J (1999) Protection against necrosis but not apoptosis by heat-stress proteins in vascular smooth muscle cells: evidence for distinct modes of cell death. Hypertension 33: 906-913

41. Force T and Bonventre JV (1998) Growth factors and mitogen-activated protein kinases. Hypertension 31: 152-161

42. McKenzie FR and Pouyssegur J (1996) cAMP-mediated growth inhibition in fibroblasts is not mediated via mitogen-activated protein (MAP) kinase (ERK) inhibition. cAMP-dependent protein kinase induces a temporal shift in growth factor-stimulated MAP kinase. J. Biol. Chem. 271: 13476-13483

43. Giasson E, Servant MJ and Meloche S (1997) Cyclic AMP-mediated inhibition of angiotensin II-induced protein synthesis is associated with suppression of tyrosine phosphorylation signaling in vascular smooth muscle cells. J. Biol. Chem. 272: $26879-26886$

44. Hadrava V, Tremblay J and Hamet P (1989) Abnormalities in growth characteristics of aortic smooth muscle cells in spontaneously hypertensive rats. Hypertension 13: 589-597

45. Orlov SN, Dam TV, Tremblay J and Hamet P (1996) Apoptosis in cultured vascular smooth muscle cells. Role of cell volume decrease. Biochem. Biophys. Res. Commun. 221: 708-715

46. Hamet P, Pang SC and Tremblay J (1989) Atrial natriuretic factor-induced egression of cyclic guanosine $3^{\prime}, 5^{\prime}$-monophosphate in cultured vascular smooth muscle cells. J. Biol. Chem. 264: $12364-12369$

47. Verheijen MHC and Defize LHK (1997) Parathyroid hormone activates mitogenactivated protein kinase via cAMP-mediated pathway independent of Ras. J. Biol. Chem. 272: 3423-3429

48. Livesey SA and Martin TJ (1988) Selective activation of the cAMP-dependent protein kinase isoenzymes. Methods Enzymol. 159: 105-118 